\title{
Overpotential analysis of alkaline and acidic alcohol electrolysers and optimized membrane-electrode assemblies
}

\author{
F. M. Sapountzi ${ }^{\mathrm{a}^{*}}$, V. Di Palma ${ }^{\mathrm{b}}$, G. Zafeiropoulos ${ }^{\mathrm{c}}$, H. Penchev ${ }^{\mathrm{d}}$, M.A. Verheijen ${ }^{\mathrm{b}}$, \\ M. Creatore ${ }^{\mathrm{b}}$, F. Ublekov ${ }^{\mathrm{d}}$, V. Sinigersky ${ }^{\mathrm{d}}$, W.M. Arnold Bik ${ }^{\mathrm{c}}$, H.O.A. Fredriksson ${ }^{\mathrm{a}}$, \\ M.N. Tsampas ${ }^{\mathrm{c}}, \mathrm{J} . \mathrm{W}$. Niemantsverdriet ${ }^{\mathrm{a}}$
}

\begin{abstract}
a SynCat@DIFFER, Syngaschem BV, P.O. Box 6336, 5600 HH, Eindhoven, The Netherlands, www.syngaschem.com

${ }^{\mathrm{b}}$ Department of Applied Physics, Eindhoven University of Technology, 5600MB, Eindhoven, The Netherlands

${ }^{c}$ DIFFER, Dutch Institute For Fundamental Energy Research, De Zaale 20, 5612 AJ, Eindhoven, The Netherlands

${ }^{\mathrm{d}}$ Institute of Polymers, Bulgarian Academy of Sciences, Acad. Georgi Bonchev 103A Str., BG 1113, Sofia, Bulgaria
\end{abstract}

*Corresponding author: Foteini Sapountzi, email: foteini@syngaschem.com, postal address: Syngaschem BV, P.O. Box 6336, 5600 HH, Eindhoven, The Netherlands

Abstract: Alcohol electrolysis using polymeric membrane electrolytes is a promising route for storing excess renewable energy in hydrogen, alternative to the thermodynamically limited water electrolysis. By properly choosing the ionic agent (i.e. $\mathrm{H}^{+}$or $\mathrm{OH}^{-}$) and the catalyst support, and by tuning the catalyst structure, we developed membrane-electrode-assemblies which are suitable for cost-effective and efficient alcohol electrolysis. Novel porous electrodes were prepared by Atomic Layer Deposition (ALD) of $\mathrm{Pt}$ on a $\mathrm{TiO}_{2}-\mathrm{Ti}$ web of microfibers and were interfaced to polymeric membranes with either $\mathrm{H}^{+}$or $\mathrm{OH}^{-}$conductivity. Our results suggest that alcohol electrolysis is more efficient using $\mathrm{OH}^{-}$conducting membranes under appropriate operation conditions (high $\mathrm{pH}$ in anolyte solution). ALD enables better catalyst utilization while it appears that the $\mathrm{TiO}_{2}$ - $\mathrm{Ti}$ substrate is an ideal alternative to the conventional carbon-based diffusion layers, due to its open structure. Overall, by using our developmental anodes instead of commercial porous electrodes, the performance of the alcohol electrolyser (normalized per mass of Pt) can be increased up to $\sim 30$ times. 
Keywords: alcohol electrolysis; hydrogen production; porous electrodes; atomic layer deposition; proton-conducting polymer; hydroxyl ion-conducting polymer

\section{Introduction}

Hydrogen is a potential energy carrier for storing excess power generated during the intermittent operation of renewable energy sources. Among the different water electrolysis technologies ${ }^{1,2}$, the use of polymeric exchange membranes (PEM) allows operation at low temperatures and production of high purity hydrogen ${ }^{2-5}$. However, the efficiency of PEM electrolysers is mainly limited by the sluggish kinetics of the oxygen evolution reaction $(\mathrm{OER})^{6}$. A promising approach to deal with this issue is to replace OER by the electrooxidation of a sacrificial agent, which can be an organic compound ${ }^{7,8}$. For the specific case of using alcohols as the sacrificial agent, the process is called alcohol electrolysis or electrochemical reforming of alcohols ${ }^{9}$. The power demands for alcohol electrolysis can be significantly lower compared to conventional water electrolysis. Table 1 gives indicatively the theoretical potentials and the half-reactions that take place for the cases full oxidation of the alcohols to $\mathrm{CO}_{2}$. Depending on numerous parameters (chemical composition and structure of electrocatalyst, $\mathrm{pH}$, electrolyte concentration etc), several other reactions can take place leading to various intermediate products $(\mathrm{CO}$, carbonates, acetic acid, acetone etc) ${ }^{10-15}$.

52 The viability of the process has been discussed by Halme et al. ${ }^{16}$ in comparison to methanol fuel cells and by Gutierrez-Guera et al. ${ }^{17}$ in comparison to the catalytic routes of alcohol reforming.

54 Finally, the electrolysis of water-alcohol solutions has potential for other applications, taking into account that short-chain alcohols are present in industrial wastewater ${ }^{18}$. The feasibility of the concept has been validated using several organic compounds ${ }^{9,19-49}$. The aim of the present study

57 is to identify promising membrane-electrode-assemblies (MEAs) which can enable cost-effective and efficient alcohol electrolysis.

59 Regarding the effect of the polymeric electrolyte, and thus the acidity/alkalinity of the anolyte 60 solution, we investigated the electrolysis of alcohol-water solutions using both $\mathrm{H}^{+}$and $\mathrm{OH}^{-}$ 61 conducting membranes. At the best of our knowledge, no comparison exists in literature between 62 alcohol-water electrolysers operating with $\mathrm{H}^{+}$and $\mathrm{OH}^{-}$conducting membranes under identical 
63 temperatures and alcohol concentrations and using the same electrode. The operation principle of the acidic $\left(\mathrm{H}^{+}\right)$and alkaline $\left(\mathrm{OH}^{-}\right)$PEM methanol-water electrolysers is presented in Fig 1 .

65

Table 1. Basic chemical reactions and theoretical potentials for different types of alcohol electrochemical reforming

67 (Only the cases of full alcohol electrooxidation at the anode are given).

\begin{tabular}{|c|c|c|c|}
\hline Alcohol & Electrochemical Reactions & Ionic agent & $E^{0}=-\Delta G^{0} / n F$ \\
\hline Methanol & $\begin{array}{l}\text { Anode: } \mathrm{CH}_{3} \mathrm{OH}+\mathrm{H}_{2} \mathrm{O} \rightarrow \mathrm{CO}_{2}+6 \mathrm{H}^{+}+6 \mathrm{e}^{-} \\
\text {Cathode: } 6 \mathrm{H}^{+}+6 \mathrm{e}^{-} \rightarrow 3 \mathrm{H}_{2} \\
\text { Total: } \mathrm{CH}_{3} \mathrm{OH}+\mathrm{H}_{2} \mathrm{O} \rightarrow \mathrm{CO}_{2}+3 \mathrm{H}_{2} \\
\text { Anode: } 6 \mathrm{H}_{2} \mathrm{O}+6 \mathrm{e}^{-} \rightarrow 6 \mathrm{OH}^{-}+3 \mathrm{H}_{2} \\
\text { Cathode: } \mathrm{CH}_{3} \mathrm{OH}+6 \mathrm{OH}^{-} \rightarrow \mathrm{CO}_{2}+5 \mathrm{H}_{2} \mathrm{O}+6 \mathrm{e}^{-} \\
\text {Total: } \mathrm{CH}_{3} \mathrm{OH}+\mathrm{H}_{2} \mathrm{O} \rightarrow \mathrm{CO}_{2}+3 \mathrm{H}_{2}\end{array}$ & $\mathrm{OH}^{-}$ & $16 \mathrm{mV}$ \\
\hline Ethanol & $\begin{array}{l}\text { Anode: } \mathrm{CH}_{3} \mathrm{CH}_{2} \mathrm{OH}+3 \mathrm{H}_{2} \mathrm{O} \rightarrow 2 \mathrm{CO}_{2}+12 \mathrm{H}^{+}+12 \mathrm{e}^{-} \\
\text {Cathode: } 12 \mathrm{H}^{+}+12 \mathrm{e}^{-} \rightarrow 6 \mathrm{H}_{2} \\
\text { Total: } \mathrm{CH}_{3} \mathrm{CH}_{2} \mathrm{OH}+3 \mathrm{H}_{2} \mathrm{O} \rightarrow 2 \mathrm{CO}_{2}+6 \mathrm{H}_{2} \\
\text { Anode: } 12 \mathrm{H}_{2} \mathrm{O}+12 \mathrm{e}^{-} \rightarrow 12 \mathrm{OH}^{-}+6 \mathrm{H}_{2} \\
\text { Cathode: } \mathrm{CH}_{3} \mathrm{CH}_{2} \mathrm{OH}+12 \mathrm{OH}^{-} \rightarrow 2 \mathrm{CO}_{2}+9 \mathrm{H}_{2} \mathrm{O}+12 \mathrm{e}^{-} \\
\text {Total: } \mathrm{CH}_{3} \mathrm{CH}_{2} \mathrm{OH}+3 \mathrm{H}_{2} \mathrm{O} \rightarrow 2 \mathrm{CO}_{2}+6 \mathrm{H}_{2}\end{array}$ & $\mathrm{OH}^{-}$ & $84 \mathrm{mV}$ \\
\hline Propanol & $\begin{array}{l}\text { Anode: } \mathrm{C}_{3} \mathrm{H}_{7} \mathrm{OH}+5 \mathrm{H}_{2} \mathrm{O} \rightarrow 3 \mathrm{CO}_{2}+18 \mathrm{H}^{+}+18 \mathrm{e}^{-} \\
\text {Cathode: } 18 \mathrm{H}^{+}+18 \mathrm{e}^{-} \rightarrow 9 \mathrm{H}_{2} \\
\text { Total: } \mathrm{C}_{3} \mathrm{H}_{7} \mathrm{OH}+5 \mathrm{H}_{2} \mathrm{O} \rightarrow 3 \mathrm{CO}_{2}+9 \mathrm{H}_{2} \\
\text { Anode: } 18 \mathrm{H}_{2} \mathrm{O}+18 \mathrm{e}^{-} \rightarrow 18 \mathrm{OH}^{-}+9 \mathrm{H}_{2} \\
\text { Cathode: } \mathrm{C}_{3} \mathrm{H}_{7} \mathrm{OH}+18 \mathrm{OH}^{-} \rightarrow 3 \mathrm{CO}_{2}+13 \mathrm{H}_{2} \mathrm{O}+18 \mathrm{e}^{-} \\
\text {Total: } \mathrm{C}_{3} \mathrm{H}_{7} \mathrm{OH}+5 \mathrm{H}_{2} \mathrm{O} \rightarrow 3 \mathrm{CO}_{2}+9 \mathrm{H}_{2}\end{array}$ & $\mathrm{OH}^{-}$ & $\begin{array}{c}106 \mathrm{mV} \\
\text { for 2-propanol }\end{array}$ \\
\hline
\end{tabular}

68

69 


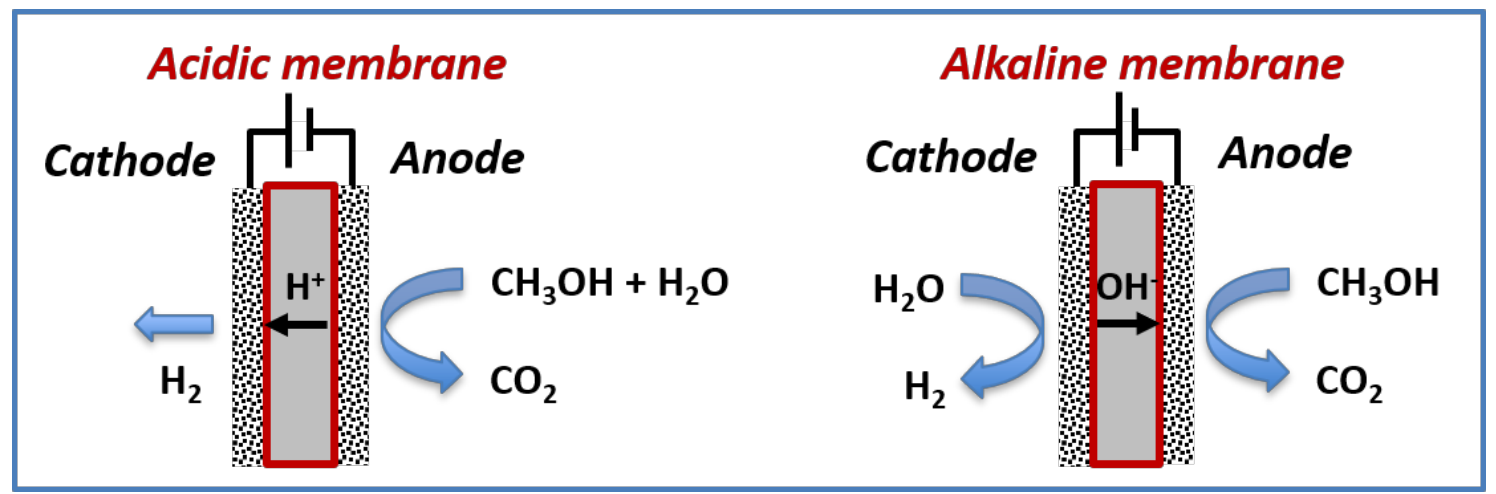

Figure 1. Operation of PEM cells during electrolysis of methanol-water solutions using polymeric membranes with $\mathrm{H}^{+}$or $\mathrm{OH}^{-}$conductivity as the electrolyte.

To optimize the electrode design and address the issue of catalyst utilization, electrodes were developed via Atomic Layer Deposition (ALD) of $\mathrm{Pt}$ on a porous $\mathrm{TiO}_{2}-\mathrm{Ti}$ substrate. For comparison reasons, identical experiments were carried out also using conventional $\mathrm{Pt} / \mathrm{C}$ on carbon cloth electrodes. ALD is a thin-film deposition technique which has recently attracted much attention for the fabrication of electrocatalysts. ALD offers uniform dispersion of sizecontrollable catalyst nanoparticles over the entire surface of $3 \mathrm{D}$ substrates ${ }^{50-52}$.

Overall, our results suggest that alcohol electrolysis can be more efficient using $\mathrm{OH}^{-}$conducting membranes under appropriate operation conditions (high $\mathrm{pH}$ in anolyte solution). Moreover, we found that the implementation of the ALD process for the electrode preparation and of alternative $\mathrm{TiO}_{2} / \mathrm{Ti}$ substrates results in up to $\sim 30$ times more efficient catalyst utilization compared to commercial electrodes (Pt on carbon cloth).

\section{Experimental section}

\subsection{Polymeric membrane with $\mathrm{H}^{+}$conductivity}

A Nafion $^{\mathrm{TM}} 117$ membrane with thickness 0.007 inch (Sigma Aldrich) was used as the protonconducting electrolyte. Prior to its use, the membrane was treated by successive immersion in 15 wt $\% \mathrm{H}_{2} \mathrm{O}_{2}, 1 \mathrm{M} \mathrm{H}_{2} \mathrm{SO}_{4}$ and deionized $\mathrm{H}_{2} \mathrm{O}$ at $80^{\circ} \mathrm{C}, 2 \mathrm{~h}$ for each step. Between each treatment step, the membrane was rinsed thoroughly with deionized $\mathrm{H}_{2} \mathrm{O}$. 


\subsection{Polymeric membrane with $\mathrm{OH}^{-}$conductivity}

94 A potassium hydroxide doped para-PBI membrane was used as the hydroxyl ion $\left(\mathrm{OH}^{-}\right)$ conducting electrolyte and was prepared by following a recently published procedure ${ }^{53}$. In short, in order to achieve high doping level of $\mathrm{KOH}$ electrolyte, we started from highly phosphoric acid doped sol-gel p-PBI membrane, which after acid washing and neutralization is subsequently redoped with $50 \mathrm{wt} \% \mathrm{KOH}$ solution. This affordable method allows much higher degree of alkali doping (and thus much higher $\mathrm{OH}^{-}$conductivity) than the traditionally applied imbibing method, where dry $\mathrm{PBI}$ is immersed in lower concentration $\mathrm{KOH}$ solutions, usually at high temperatures for a prolonged time.

\subsection{Porous electrode preparation}

The geometric surface area of anode and cathode was $3.1 \mathrm{~cm}^{2}$. Commercial $1 \mathrm{mg} / \mathrm{cm}^{2} \mathrm{Pt}(20 \%$ $\mathrm{Pt} / \mathrm{C}$ ) on carbon cloth was used for the cathode during all experiments. Two different kinds of porous electrodes served as the anode of the cell: commercial electrodes with $1 \mathrm{mg} / \mathrm{cm}^{2} \mathrm{Pt}(20 \%$ $\mathrm{Pt} / \mathrm{C}$ ) loaded on carbon cloth (ElectroChem Inc.) and electrodes fabricated via Atomic Layer Deposition (ALD) of $\mathrm{Pt}$ on a porous $\mathrm{TiO}_{2}-\mathrm{Ti}$ substrate (where $\mathrm{TiO}_{2}$ represents the native oxide surface). As described elsewhere ${ }^{54}$, Ti-felts (Bekinit, $20 \mu \mathrm{m}$ microfibers, $80 \%$ porosity) were cleaned by sonication in acetone and in ethanol for $20 \mathrm{~min}$, respectively and rinsed with deionized water.

Pt was deposited on the porous $\mathrm{TiO}_{2}$-Ti felt by 100 ALD cycles using a home-made deposition system described in detail elsewhere ${ }^{55}$. The base pressure of the reactor was $<10^{-6}$ mbar. $\mathrm{MeCpPtMe}_{3}$ (98\% from Sigma Aldrich) was used as precursor and $\mathrm{O}_{2}$ gas at 1 mbar as reactant. The precursor was contained in a stainless steel cylinder, heated at $30{ }^{\circ} \mathrm{C}$, and brought into the reactor using Ar as carrier gas. The lines from the precursor to the reactor were heated to $50{ }^{\circ} \mathrm{C}$ and the reactor wall to $90{ }^{\circ} \mathrm{C}$. The ALD recipe starts by dosing $\mathrm{MeCpPtMe}_{3}$ for $4 \mathrm{~s}$, then using 3 $\mathrm{s}$ of Ar to purge the precursor line, followed by $3 \mathrm{~s}$ of pumping down. Then $\mathrm{O}_{2}$ gas is dosed for $10 \mathrm{~s}$ and afterwards the reactor is pumped down for $10 \mathrm{~s}$. The deposition was carried out with the substrate holder maintained at $300{ }^{\circ} \mathrm{C}$. 


\subsection{Characterization of Pt/TiO 2 -Ti prepared by $\mathrm{ALD}$}

123 The surface morphology of the $\mathrm{Pt} / \mathrm{TiO}_{2}-\mathrm{Ti}$ electrode was characterized with a scanning electron microscope (FEI Quanta 3D FEG, at an acceleration voltage of $15 \mathrm{keV}$ and working distance of $10 \mathrm{~mm}$ ) and transmission electron microscope (JEOL ARM 200 probe corrected TEM, operated at $200 \mathrm{kV}$, equipped with a $100 \mathrm{~mm}$ Centurio SDD EDS detector). The TEM sample was created by peeling off individual fibers from the sample, and subsequently gluing them to a copper support. The fibers themselves were far too thick to be electron transparent. In some thin edges of the fibers, Pt particles could be imaged. Based on the open structure of the fiber network we assumed that the images show a Pt distribution that is representative for the entire sample.

Rutherford Backscattering (RBS) analysis ${ }^{56}$ was performed with a $2 \mathrm{MeV}^{4} \mathrm{He}$ beam delivered by the 3.5 MV HVE Singletron installed at DIFFER (figure S1). In this particular case, the angle of incidence could not be freely chosen and amounted to $41^{\circ}$ with respect to the sample normal. The particle detector was located at a scattering angle of $147^{\circ}$, resulting in an $8^{\circ}$ exit angle of the scattered particles with the sample normal. The combination of the non-perpendicular incidence angle with the fiber-like texture of the samples gave rise to shadowing effects; a large fraction of the incidence ions reached the sample 'under' fibers which blocked scattered particles on their way to the detector. Fortunately, this fraction was equal for all samples and amounted to $37 \pm 3 \%$. The Pt loading is determined by simulation performed by WiNDF ${ }^{57}$. For these simulations, $63 \%$ of the actual charge has been used. The final Pt loading is estimated to be $0.025 \mathrm{mg} / \mathrm{cm}^{2}$, which has a similar order of magnitude to reported loadings after $100 \mathrm{Pt}$ LD cycles on electrodes for PEM fuel cells ${ }^{58}$.

\subsection{Experimental setup and methods}

The experiments were carried out in a dual-chamber, separated electrochemical reactor made from borosilicate glass (Pine Research Instrumentation, figure S2) as described elsewhere ${ }^{44}$. The catholyte chamber was filled with $0.3 \mathrm{M} \mathrm{H}_{2} \mathrm{SO}_{4}$ or $0.3 \mathrm{M} \mathrm{KOH}$ solution for the experiments with $\mathrm{H}^{+}$and $\mathrm{OH}^{-}$conducting membranes respectively. The alcohols (methanol, ethanol, iso-propanol, Sigma Aldrich, $>99.5 \%$ ) were introduced in the anolyte after mixing with proper amounts of 
$150 \mathrm{H}_{2} \mathrm{SO}_{4}$ or $\mathrm{KOH}$ solutions. Between studies of different alcohols, the MEA was washed by 151 immersion in ultrapure water and dried in air at $70^{\circ} \mathrm{C}$.

152 The experiments were carried out at room temperature. Polarization data were collected using an 153 Ivium Vertex potentiostat, equipped with an integrated impedance interface. The cell impedance 154 was measured using a frequency range from $10 \mathrm{kHz}$ to $10 \mathrm{mHz}$ with a potential amplitude of 10 $155 \mathrm{mV}$. All overpotential values are calculated versus the potential at zero cell current.

157 3. Results and discussion

158 3.1. Acidic vs alkaline membranes

159 Figure 2 gives a comparison of the potential losses when alcohol electrolysis is carried out with $160 \mathrm{H}^{+}$or $\mathrm{OH}^{-}$conducting membranes. The total cell overpotential, $\eta_{\text {total }}$, is shown together with its 161 anodic $\left(\eta_{a n}\right)$, cathodic $\left(\eta_{c a t h}\right)$ and ohmic $\left(\eta_{o h m}\right)$ components. For the experiments of Figure 2 , a 162 commercial anode of $\mathrm{Pt} / \mathrm{C}$ on carbon cloth was used during the electrolysis of methanol, ethanol 163 and iso-propanol.

164

165

166

167

168

169

170

171

172

173

174

175 


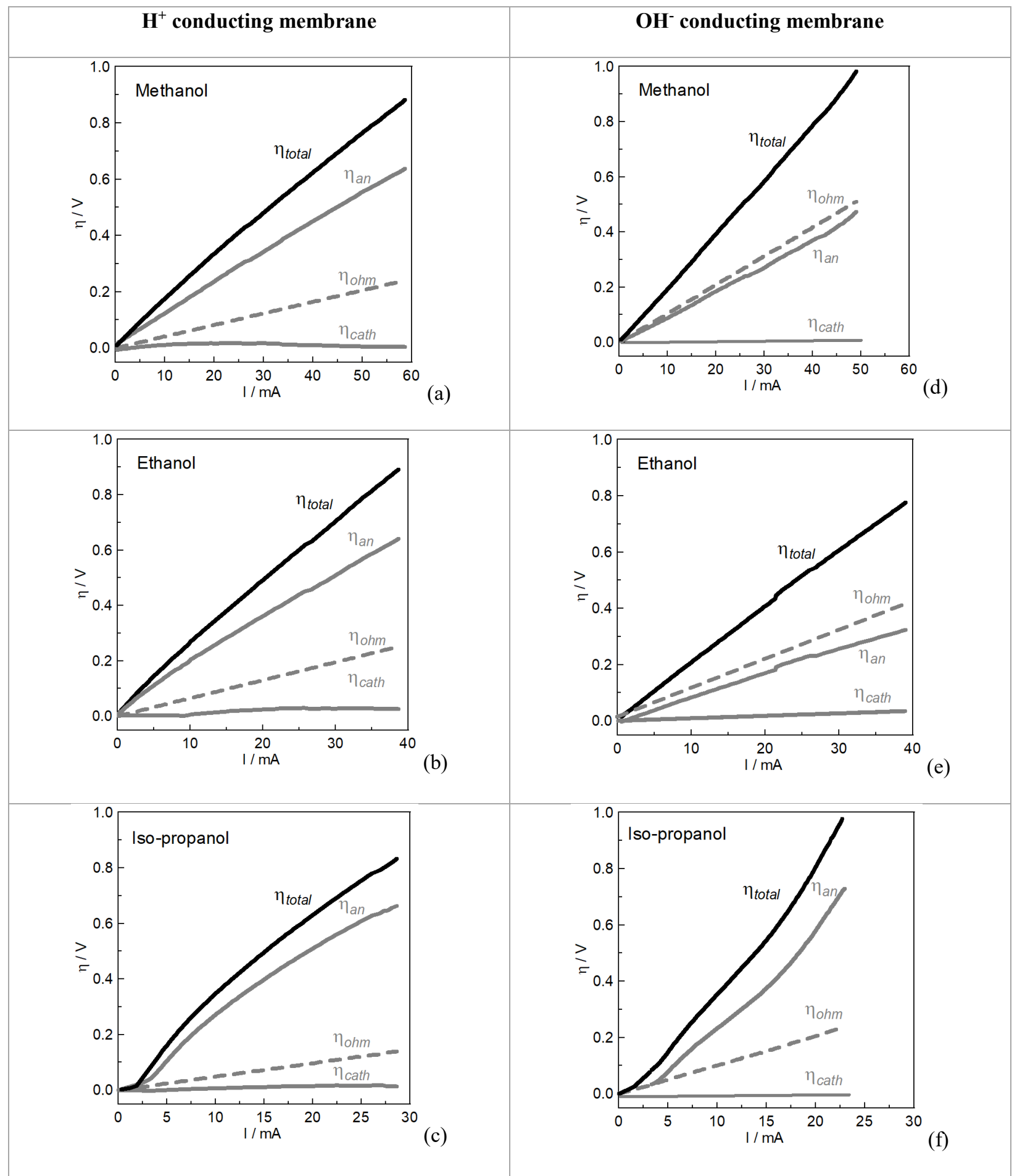

176

177

178

179

180

Figure 2. Effect of the cell current on the total cell overpotential and on the individual anodic, cathodic and ohmic overpotentials for $(\mathrm{a}, \mathrm{d})$ methanol, $(\mathrm{b}, \mathrm{e})$ ethanol, $(\mathrm{c}, \mathrm{f})$ iso-propanol. Figures $\mathrm{a}, \mathrm{b}, \mathrm{c}$ correspond to operation with $\mathrm{H}^{+}$ conducting polymeric membrane (Nafion) and data are obtained by our previous study ${ }^{44}$, Figures d, e, f correspond to operation with $\mathrm{OH}^{-}$conducting polymeric membrane (KOH doped-PBI). Forward scans are presented. Sweep rate is $10 \mathrm{mV} / \mathrm{s}$. Anolyte: $5.5 \mathrm{M}$ alcohol + $0.2 \mathrm{M} \mathrm{H}_{2} \mathrm{SO}_{4}(\mathrm{a}, \mathrm{b}, \mathrm{c})$ or $0.2 \mathrm{M} \mathrm{KOH}(\mathrm{d}, \mathrm{e}, \mathrm{f})$. 
182 As discussed in our previous $\operatorname{study}^{44}$ for the case of $\mathrm{H}^{+}$conducting electrolyte (Nafion), 183 overpotentials mainly originate from the slow anodic reaction (alcohol electrooxidation). In this study we replaced Nafion by an $\mathrm{OH}^{-}$conducting membrane ( $\mathrm{KOH}$ doped $\mathrm{PBI}$ ), and we observed that the anodic losses become much lower for both methanol and ethanol electrolysis, while on the other hand ohmic losses become larger. It is well-known that alkaline membranes cannot reach the conductivity of Nafion ${ }^{59}$. As a result, with the $\mathrm{KOH}$ doped-PBI membrane, anodic and ohmic losses contribute almost equally to the total cell losses for the cases of methanol and ethanol electrolysis. A small cathodic overpotential $(\sim 60 \mathrm{mV})$ was observed only during ethanol electrolysis using the alkaline membrane. As discussed later, this observation is in line with EIS measurements and can be attributed to extended ethanol crossover through the polymeric membrane that causes the blocking of the cathodic active sites. The performance during electrolysis of iso-propanol shows high anodic overpotentials at both acidic and alkaline polymeric electrolytes, suggesting that iso-propanol electrolysis is not a viable technology under the tested conditions. We assume that the high anodic overpotentials obtained with iso-propanol are mainly related to the formation of strongly adsorbed intermediates ${ }^{44-60}$.

The beneficial role of the alkaline membranes towards the minimization of anodic losses is clearly depicted in Table 2. The observed behaviour is in agreement with fundamental studies on alcohol electrooxidation in aqueous media which have demonstrated an increased electrocatalytic activity at alkaline $\mathrm{pH}^{61-62}$. Even though the use of $\mathrm{OH}^{-}$conducting membranes seems a priori as more promising for alcohol electrolysis due to the enhanced kinetics at high $\mathrm{pH}$, the majority of studies in the field utilize polymeric electrolytes with $\mathrm{H}^{+}$conductivity. Tuomi et al. ${ }^{31}$ were the first to carry out electrolysis of methanol-water solutions using an $\mathrm{OH}^{-}$conducting polymeric membrane. However, the obtained overall performance was inferior to previous studies with $\mathrm{H}^{+}$ conducting membranes, but it was unclear to the authors if this was related to the lower metal loading used in their study or to the low ionic conductivity of the alkaline membrane. Our analysis is performed using anodes with identical metal loadings and indicates that even though electrocatalysis is favored at alkaline media (anodic overpotentials are lower, Table 2), the high ohmic losses associated with the slow $\mathrm{OH}^{-}$transport through the doped-PBI membrane have a great impact on the overall performance of the electrolyser under the operational conditions of the experiment of figure 2 . 
Table 2. Comparison of the current for different values of anodic overpotential, ionic agents and kinds of alcohol.

213 Data for Nafion are obtained from literature ${ }^{44}$.

\begin{tabular}{|c|c|c|c|c|c|c|}
\hline \multirow{3}{*}{$\begin{array}{c}\text { Anodic } \\
\text { overpotential }\end{array}$} & \multicolumn{6}{|c|}{ Current / mA } \\
\hline & \multicolumn{2}{|c|}{ Methanol } & \multicolumn{2}{|c|}{ Ethanol } & \multicolumn{2}{|c|}{ Iso-propanol } \\
\hline & $\mathrm{H}^{+}$ & $\mathrm{OH}^{-}$ & $\mathrm{H}^{+}$ & $\mathrm{OH}^{-}$ & $\mathrm{H}^{+}$ & $\mathrm{OH}^{-}$ \\
\hline $0.2 \mathrm{~V}$ & 17.1 & 21.9 & 10.1 & 21.4 & 6.8 & 7.3 \\
\hline $0.3 \mathrm{~V}$ & 25.9 & 33.0 & 15.9 & 33.0 & 10.8 & 11.3 \\
\hline $0.4 \mathrm{~V}$ & 35.4 & 43.9 & 22.5 & 43.7 & 14.7 & 14.6 \\
\hline
\end{tabular}

However, the comparison between acidic and alkaline electrolysers should be carried out carefully, since the operational parameters can greatly affect the performance. Specifically, the ionic conductivity of alkaline membranes is known to show high dependence on the $\mathrm{KOH}$ concentration $^{63-67}$. On the other hand, it has been reported that the performance of ethanol electrolysers with acidic membranes can be enhanced up to $20 \%$ upon properly adjusting the $\mathrm{pH}$ (by tuning the $\mathrm{H}_{2} \mathrm{SO}_{4}$ concentration in the anolyte feed), but this effect is only related to electrocatalytic properties of the anode since the ohmic resistance of Nafion remained unchanged upon $\mathrm{pH}$ variations in the acidic regime ${ }^{68}$. To allow a more fair comparison, we performed measurements with identical electrochemical cells operated with different $\mathrm{KOH}$ concentration in the anolyte solution. A $~ 70 \%$ increase in the overall cell performance was obtained by increasing the $\mathrm{KOH}$ concentration in the anolyte solution (figure 3a) by a factor of five. Deconvolution of the overpotential losses indicated that the improved overall performance under the more alkaline anolyte is only the result of enhanced ionic conductivity (figure 3c). The ohmic overpotential was the only type of overpotential affected by the changes in $\mathrm{KOH}$ concentration, as a result of higher ionic conductivity of the doped-PBI and also of the alcohol-KOH solution. As figure $3 \mathrm{~b}$ shows, the anodic overpotential remains unchanged over the investigated current range upon alterations in the alkalinity of the anolyte solution, implying that electrocatalysis is not affected by the changes in $\mathrm{KOH}$ concentration from $0.2 \mathrm{M}$ to $1.0 \mathrm{M}$. Overall, the results of figure 3 clearly indicate that under proper operation conditions, alcohol electrolysers with alkaline membranes are more appropriate for practical applications, compared to those operated with acidic membranes. 

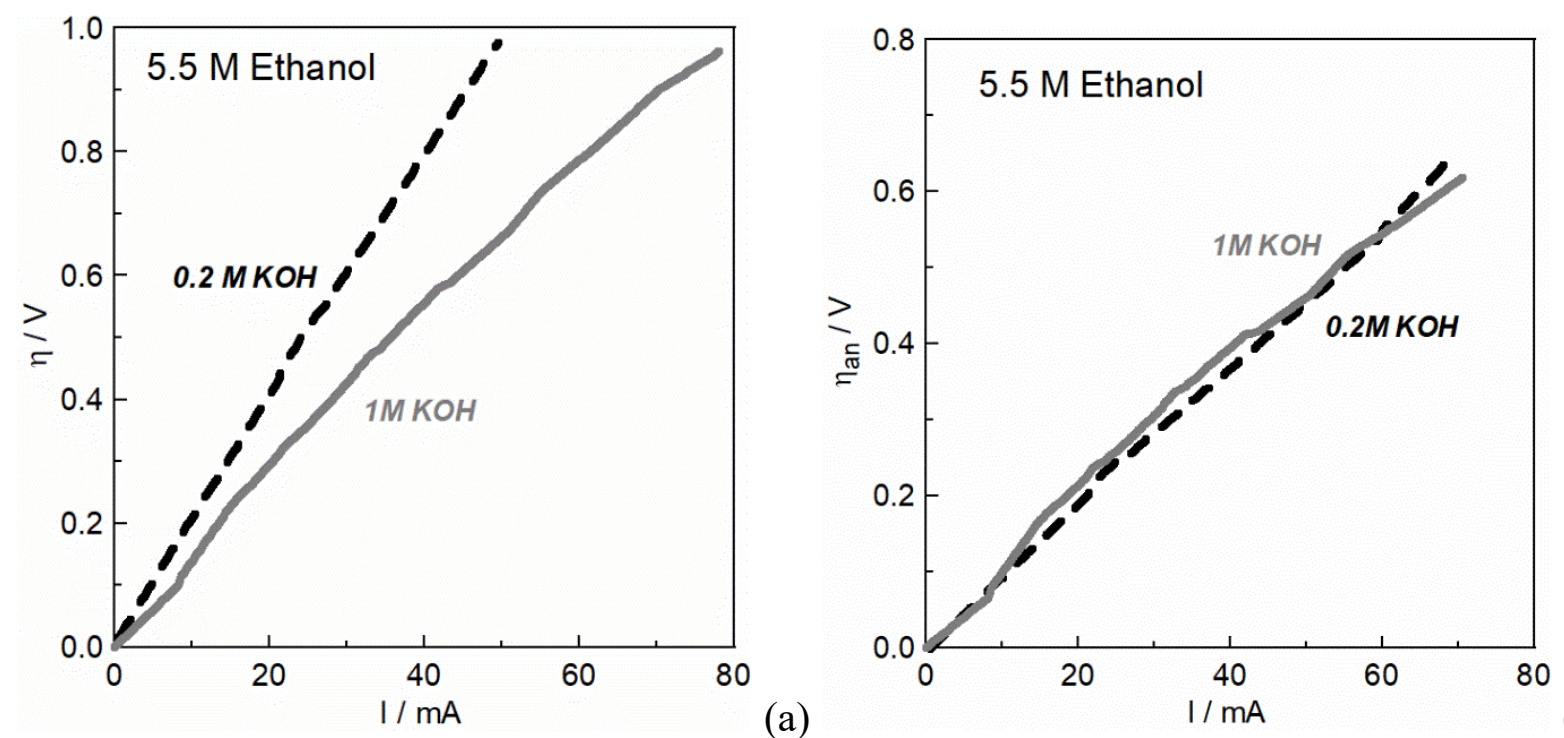

(b)

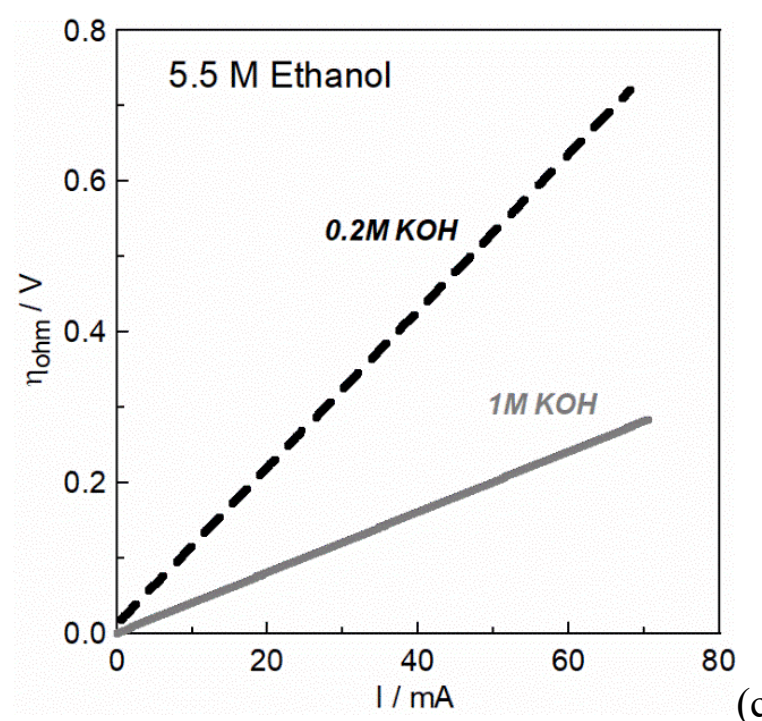

Figure 3. The dependence of current on total (a), anodic (b) and ohmic (c) overpotential using the doped-PBI membrane during electrolysis of $5.5 \mathrm{M}$ ethanol mixed with $0.2 \mathrm{M}$ and $1.0 \mathrm{M} \mathrm{KOH}$ solutions. Sweep rate is $10 \mathrm{mV} / \mathrm{s}$.

243 Electrochemical Impedance Spectroscopy (Figure 4) was used to further characterize the 244 electrolysers. As discussed in our previous study ${ }^{44}$, the ohmic resistance is affected by the 245 presence of alcohols for the case of Nafion-based cells (4.1, 6.5 and 5.0 $\Omega$ for methanol, ethanol and iso-propanol respectively) indicating that interfacial phenomena take place and lead to ohmic 
247 losses (changes in Nafion conductivity or membrane swelling). On the other hand, the ohmic 248 losses remain unchanged for the case of doped-PBI (10.4 $\Omega$ ), indicating that these interfacial 249 phenomena are suppressed (the presence of alcohols causes less degree of swelling and/or 250 negligible changes in the ionic conductivity of doped PBI membranes).

251 The low-frequency semicircle at the Nyquist plot is related to the anodic reaction since it is 252 clearly affected by the kind of alcohol and the type of polymeric membrane. The high-frequency 253 semicircle at the Nyquist plot is related to the cathodic hydrogen evolution reaction. Its width is 254 related with the cathodic charge transfer resistance, which is independent of the nature of the 255 alcohol for the case of Nafion, while it shows a small dependence on the alcohols for the case of $256 \mathrm{KOH}$ doped-PBI (7.8, 8.6 and $7.9 \Omega$ for methanol, ethanol and iso-propanol respectively). The 257 higher cathodic resistance (figure 4) and cathodic overpotential (figure 2e) observed only in 258 presence of ethanol, provide evidence for extended ethanol crossover through the KOH doped259 PBI membrane.

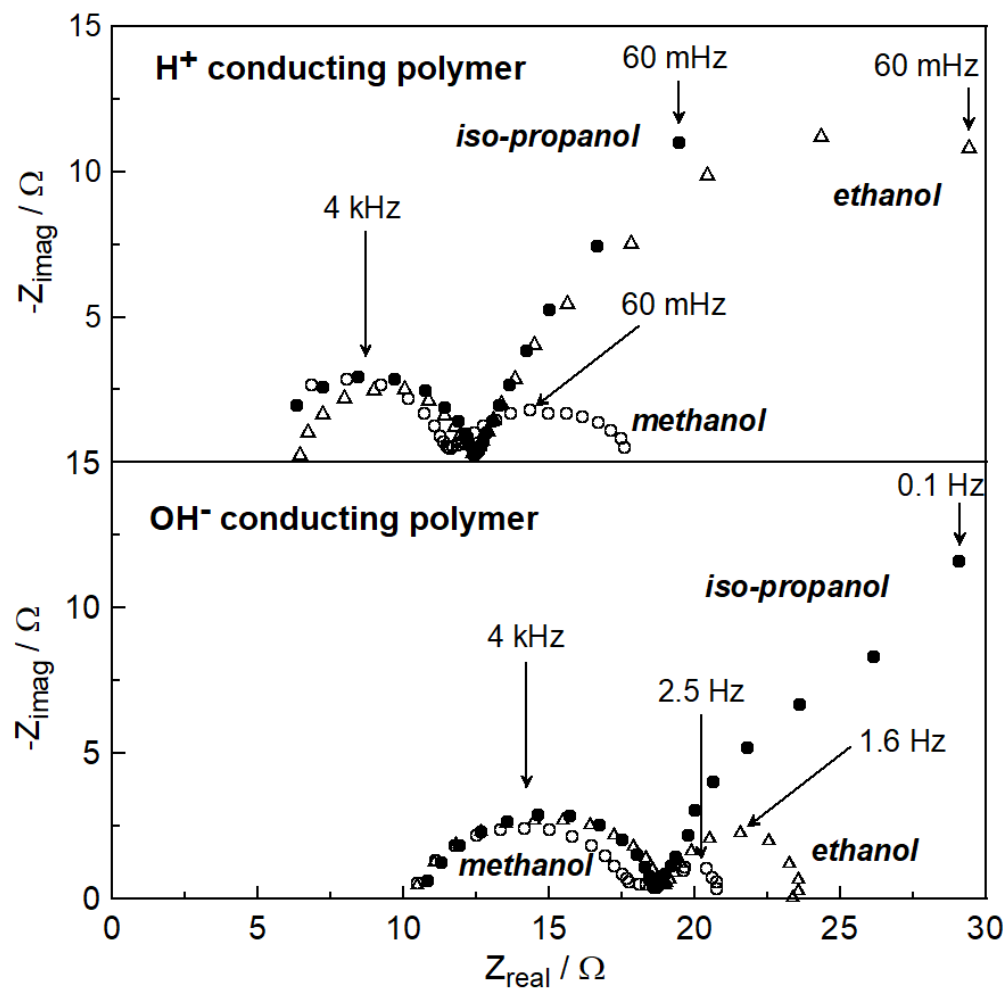

261 Figure 4. Nyquist spectra at open-circuit conditions with different alcohols using Nafion (top) and doped-PBI 262 (bottom) polymeric electrolytes. Anolyte: $5.5 \mathrm{M}$ alcohol + $0.2 \mathrm{M} \mathrm{H}_{2} \mathrm{SO}_{4}$ or $0.2 \mathrm{M} \mathrm{KOH}$. Data for Nafion adopted 263 from reference 44. 


\subsection{Novel porous electrodes}

266 As described in the experimental section, we explored a novel type of electrode by using ALD 267 for depositing $\mathrm{Pt}$ on a porous $\mathrm{TiO}_{2}$-Ti substrate. TEM images of the $\mathrm{Pt} / \mathrm{TiO}_{2}$ - $\mathrm{Ti}$ electrode are 268 shown in Figure 5. The presence and uniform distribution of the Pt particles can be clearly 269 discerned. Pt nanoparticles with an average size of $10 \mathrm{~nm}$ were obtained, but larger agglomerates 270 are also present.

271 This electrode was interfaced to the one side of Nafion and KOH doped-PBI membranes and 272 served as the anode during methanol electrolysis in acidic and alkaline media, while using a 273 commercial Pt/carbon cloth cathode.
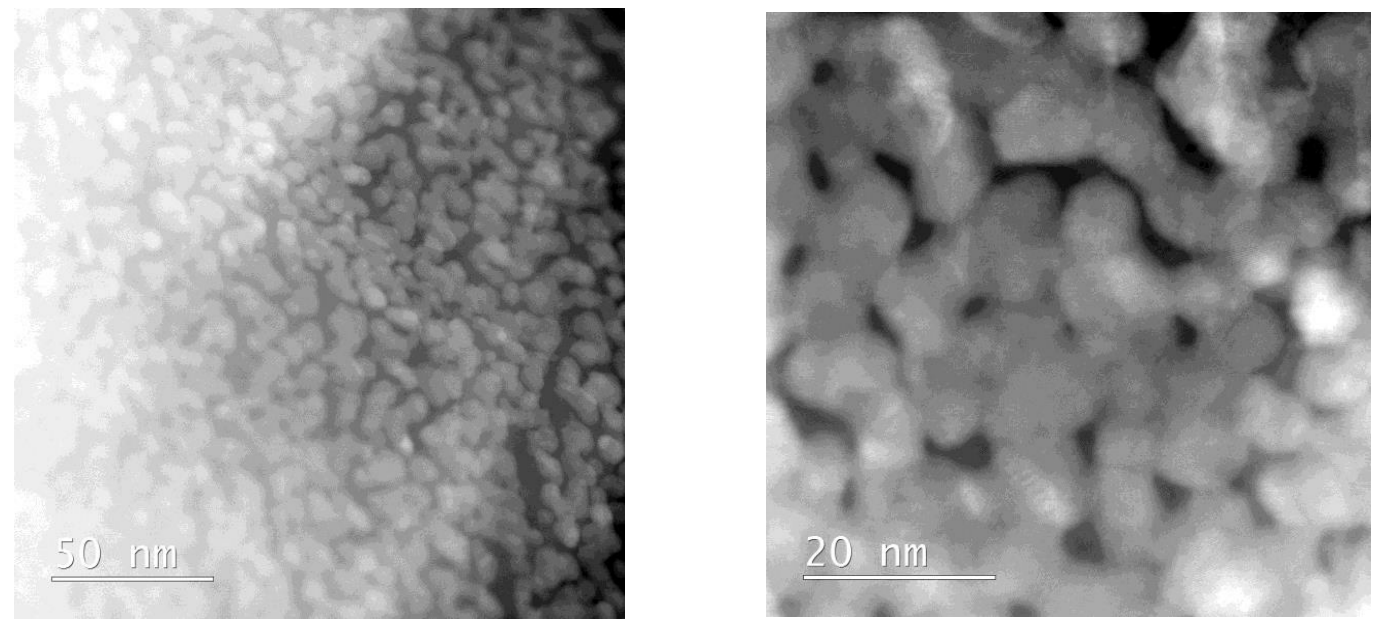

281

Figure 5. HAADF-STEM images displaying the Pt particle size on $\mathrm{TiO}_{2}$-Ti substrate after 100 ALD 282 cycles.

284 Figure 6 shows the overall cell performance when using as the anode the novel $\mathrm{Pt} / \mathrm{TiO}_{2}-\mathrm{Ti}$ 285 electrode and the commercial $\mathrm{Pt} / \mathrm{C}$ electrode. To enable comparison, per-mass normalized currents $(\mathrm{j})$ are presented in the polarization curves, while for better visualization $\mathrm{j}$ values are 287 multiplied by a factor of 10 for the case of commercial $\mathrm{Pt} / \mathrm{C}$ anode. The $\mathrm{Pt} / \mathrm{TiO}_{2}-\mathrm{Ti}$ allowed for 288 up to 30 times higher Pt utilization compared to commercial electrodes when used with the KOH-doped PBI membrane. When interfaced to Nafion membrane, the novel electrode shows up to 10 times larger mass-normalized currents over the commercial electrode. 

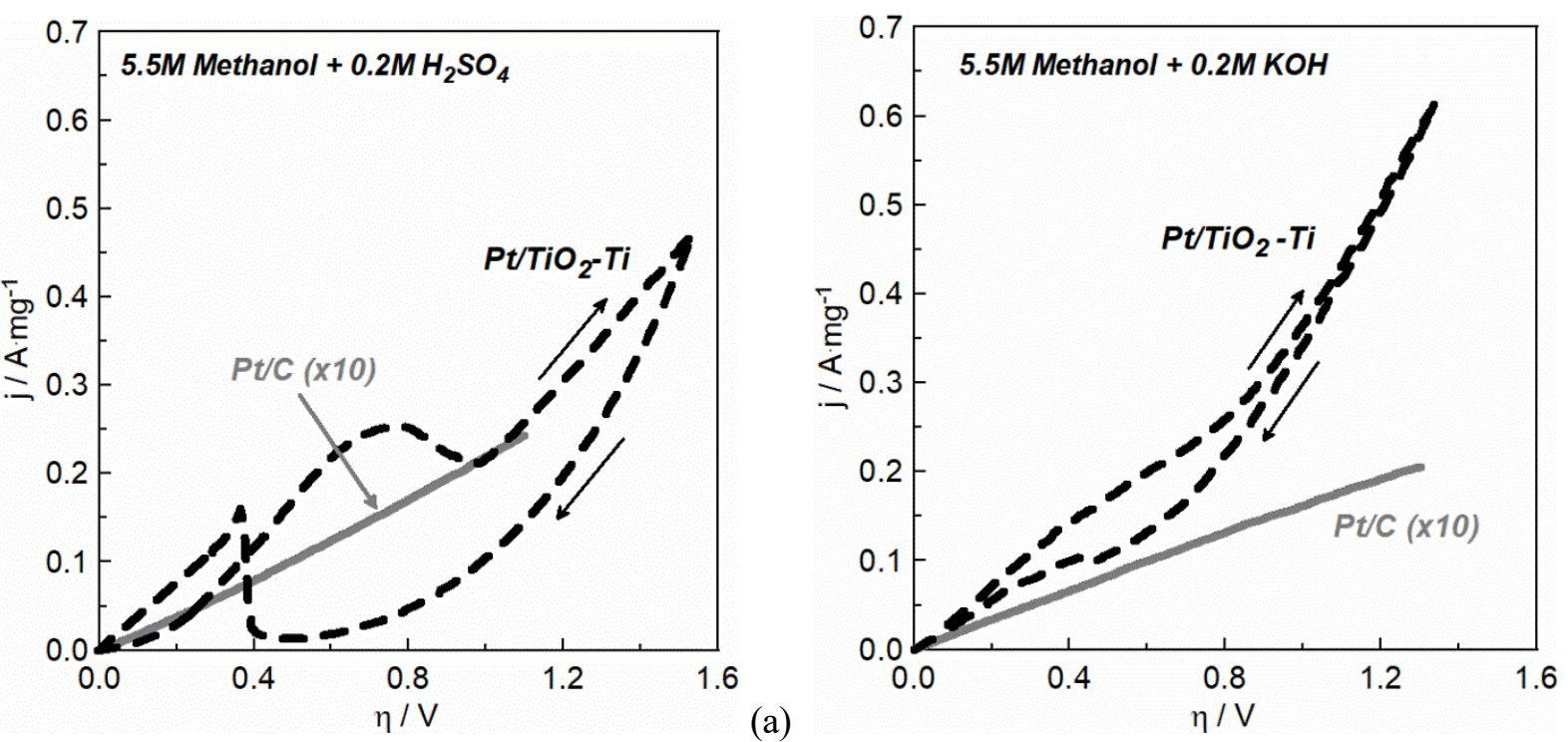

(b)

292

293

294

295

296

297

298

299

300

301

302

303

304

305

306

307

308

309

310

Figure 6. Polarization curves during methanol electrolysis using the novel $\mathrm{Pt}(\mathrm{ALD}) / \mathrm{TiO}_{2}-\mathrm{Ti}$ electrode and the commercial Pt/C carbon cloth electrode interfaced to (a) Nafion and (b) the doped-PBI membrane. Anolyte: $5.5 \mathrm{M}$ methanol mixed with (a) $0.2 \mathrm{M} \mathrm{H}_{2} \mathrm{SO}_{4}$ and (b) $0.2 \mathrm{M} \mathrm{KOH}$ solutions. Normalized current densities are 10 times multiplied for $\mathrm{Pt} / \mathrm{C}$. Sweep rate is $10 \mathrm{mV} / \mathrm{s}$.

Literature studies have reported 5-10 fold enhancement in the performance of PEM fuel cells and water electrolysers upon depositing Pt by ALD on carbon-based diffusion layers, which is typically attributed to the uniform structural characteristics of Pt due to the deposition technique ${ }^{50,69}$. We believe that in our case, the difference in performance is related to both the different Pt characteristics between the two anodes ${ }^{70}$ (loading, particle size, particles geometry) and also to the open structure of the $\mathrm{TiO}_{2}$-Ti substrate which facilitates the transport of reactants and products ${ }^{71-72}$. It has been observed in literature, that the use of $\mathrm{TiO}_{2}$-based supports instead of C-based, can induce metal-support interactions which affect the electrocatalytic oxidation of alcohols ${ }^{73-74}$. However, it is not clear if these phenomena play a role also in our system.

Another interesting feature is the complexity of the voltammograms of figure 6. Forward and backward scans were identical with the $\mathrm{Pt} / \mathrm{C}$ anode, while this is not the case for $\mathrm{Pt} / \mathrm{TiO}_{2}-\mathrm{Ti}$. As shown in figure 6a, peaks in the voltammogram are observed due to the formation/oxidation of intermediate carbonaceous species. Using the doped-PBI, the hysteresis characteristics are suppressed and the voltammogram becomes less complex. This could be due to different reaction 
311 mechanisms in acidic and alkaline media and to less accumulation of adsorbed intermediate 312 species.

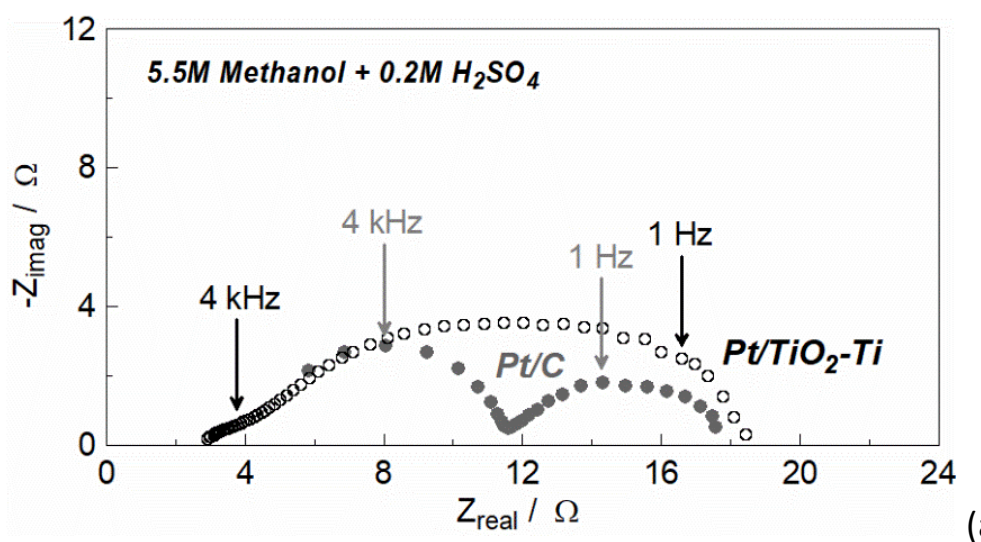

(a)

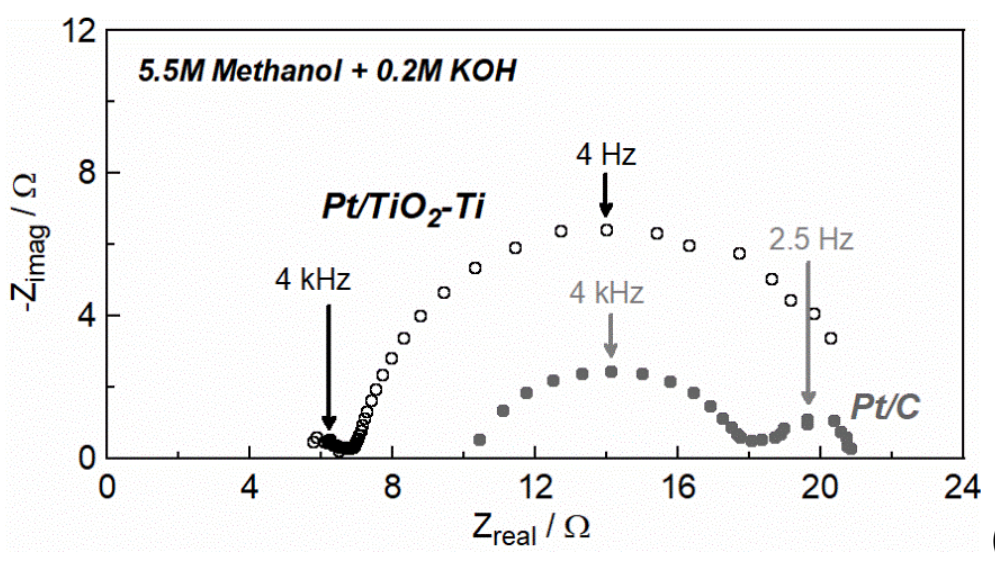

(b)

316 Figure 7. Nyquist spectra during methanol electrolysis using the $\mathrm{Pt} / \mathrm{TiO}_{2}-\mathrm{Ti}$ electrode and the commercial $\mathrm{Pt} / \mathrm{C}$ carbon cloth electrode interfaced to (a) Nafion and (b) the KOH doped-PBI membrane. Anolyte: $5.5 \mathrm{M}$ methanol mixed with (a) $0.2 \mathrm{M} \mathrm{H}_{2} \mathrm{SO}_{4}$ and (b) $0.2 \mathrm{M} \mathrm{KOH}$ solutions.

Figure 7 presents the Nyquist plots during methanol electrolysis using the two different anodes together with Nafion and the doped-PBI membrane. The semicircles in the Nyquist plots merge when the novel anodes are used, indicating comparable time-constants of the anodic and cathodic reactions. The ohmic resistance of the cell is lower for the cell with the $\mathrm{Pt} / \mathrm{TiO}_{2}-\mathrm{Ti}$ anode.

324 Specifically, the ohmic resistance with the Nafion-based cells is $2.9 \Omega$ for $\mathrm{Pt} / \mathrm{TiO}_{2}$-Ti anode and $4.1 \Omega$ for the $\mathrm{Pt} / \mathrm{C}$ anode, while with the cells with the $\mathrm{KOH}$ doped-PBI electrolyte the ohmic resistance is $6.9 \Omega$ for $\mathrm{Pt} / \mathrm{TiO}_{2}-\mathrm{Ti}$ anode and $10.4 \Omega$ for the $\mathrm{Pt} / \mathrm{C}$ anode (figure 7 ). Based on the 
327

Table 3. Polarization data and overpotential values for acidic and alkaline methanol electrolysis with $\mathrm{Pt} / \mathrm{C}$ and $\mathrm{Pt} / \mathrm{TiO}_{2}$-Ti anodes.

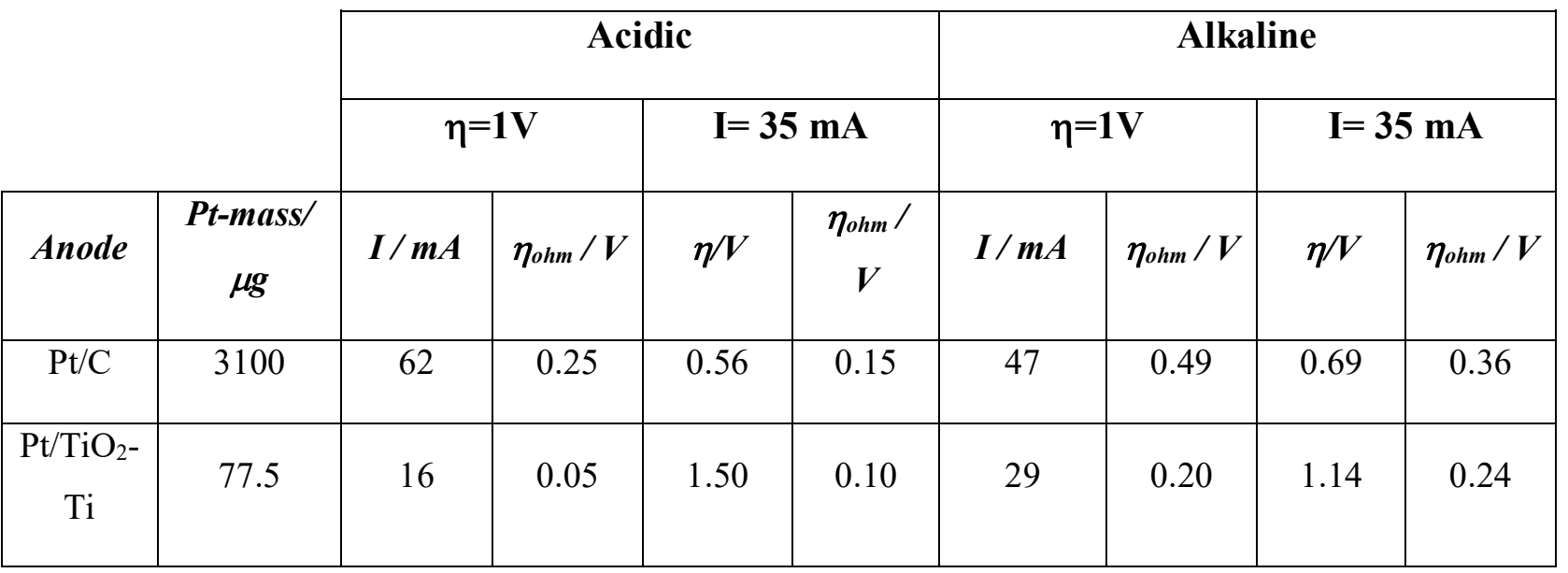
performance of the electrolysers in terms of current and ohmic and total overpotentials.

332

333 EIS measurements using the plain substrates without any Pt loading also confirmed the lower 334 resistance of the $\mathrm{TiO}_{2}$-Ti substrate (figure 8). In our view, this difference can be attributed to the 335 presence of a hydrophobic microporous layer on the carbon cloth, but not on the $\mathrm{TiO}_{2}-\mathrm{Ti}$ 336 substrate, and which can affect negatively the conductivity of gas diffusion substrates ${ }^{75-76}$.

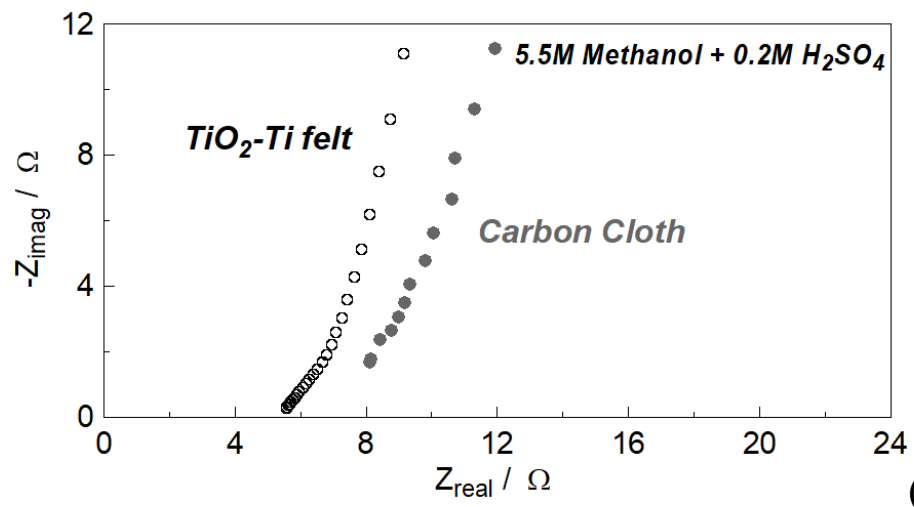




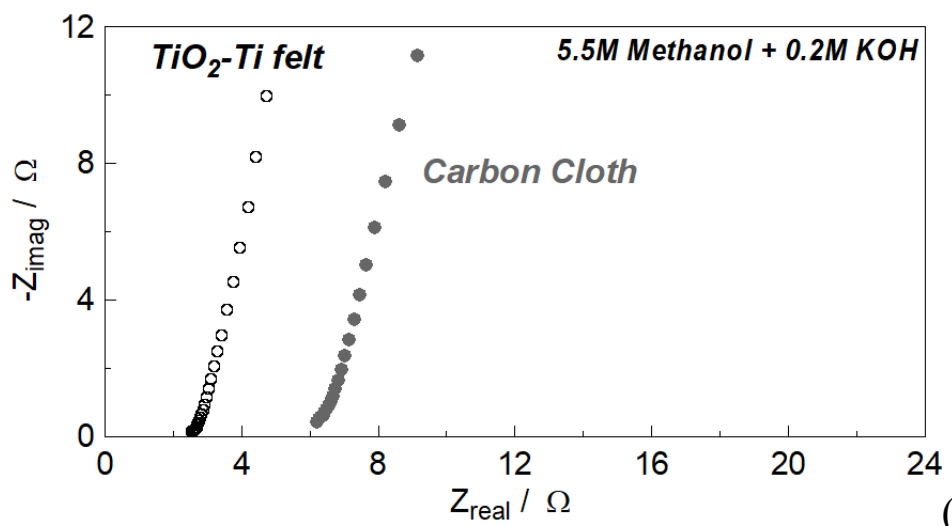

339

340

341

342

343

344

345

346

347

348

349

350

351

352

353

354

355

356

357

358

359

360

Figure 8. Nyquist spectra during methanol electrolysis using the plain $\mathrm{TiO}_{2}-\mathrm{Ti}$ and carbon cloth substrates (no Pt loading) interfaced to (a) Nafion and (b) the doped-PBI membrane. Anolyte: $5.5 \mathrm{M}$ methanol with (a) $0.2 \mathrm{M} \mathrm{H}_{2} \mathrm{SO}_{4}$ and (b) $0.2 \mathrm{M} \mathrm{KOH}$ solutions.

\section{Conclusions}

Optimized membrane-electrode-assemblies were developed for the electrolysis of C1-C3 alcohols, by properly selecting the kind of polymeric electrolyte and by designing optimized porous electrodes. In order to investigate the effect of the electrolyte, we carried out identical experiments of alcohol electrolysis with commercial electrodes using $\mathrm{H}^{+}$and $\mathrm{OH}^{-}$conducting polymeric membranes. The experiments were carried out under identical temperatures and alcohol concentrations and using the same electrode, while the $\mathrm{pH}$ of the anolyte solution was adjusted accordingly.

By deconvoluting the overpotential components, we found that the performance of both alkaline and acidic electrolysers is limited by potential losses due to slow alcohol electrooxidation (anodic overpotential) and slow ion transfer (ohmic overpotential). Anodic overpotential is diminished when $\mathrm{OH}^{-}$conducting polymers are used as the electrolyte (KOH-doped $\left.\mathrm{PBI}\right)$, in agreement with literature studies using aqueous electrolyte solutions which report increased reaction rates in alkaline media. On the other hand, the ohmic losses in the $\mathrm{OH}^{-}$conducting alcohol electrolyser are higher, due to the lower conductivity of these membranes compared to the $\mathrm{H}^{+}$conducting Nafion. However, the conductivity of $\mathrm{KOH}$-doped PBI membranes can be tuned by changing the $\mathrm{pH}$ of the anolyte solution. Overall, our results suggest that under 
appropriate operation conditions (high $\mathrm{pH}$ ), alkaline alcohol electrolysis can be more efficient than acidic alcohol electrolysis, since both anodic and ohmic overpotentials are minimized.

The second goal of this study was to design novel anodes with enhanced catalyst utilization. For this reason, Atomic layer Deposition of $\mathrm{Pt}$ was carried out on a porous $\mathrm{TiO}_{2}-\mathrm{Ti}$ substrate and the developmental anode was implemented in alkaline and acidic electrolysers. Up to 30 times more efficient catalyst utilization was achieved compared to the commercial Pt on carbon cloth anodes, as a result of optimized morphological electrode characteristics.

\section{Acknowledgements}

This project has received funding from the European Union's Horizon 2020 research and innovation programme "CritCat" under grant agreement No 686053, from Synfuels China Technology Co. Ltd (Beijing-Huairou, P.R. China) and from the Bulgarian Science Fund project DFNI-E02/9. Solliance and the Dutch province of Noord-Brabant are acknowledged for funding the TEM facility.

\section{References}

1. Chorkendorff I, Niemantsverdriet JW, Concepts of Modern Catalysis and Kinetics, $3^{\text {rd }}$ Edition Wiley-VCH, Weinheim; 2017. ISBN:978-3-527-33268-7

2. Sapountzi, F.M., Gracia JM, Fredriksson HOA, Weststrate CJ, Niemantsverdriet JW, Electrocatalysts for the generation of hydrogen, oxygen and synthesis gas. Prog Energy Combust Sci 2017; 58: 1-35. doi: 10.1016/j.pecs.2016.09.001

3. Carmo M, Fritz DL, Mergel J, Stolten D. A comprehensive review on PEM water electrolysis. Int J Hydrogen Energy 2013;38:4901-34. doi:10.1016/j.ijhydene.2013.01.151.

4. Ferrero D, Lanzini A, Santarelli M, Leone P. A comparative assessment on hydrogen production from low- and high-temperature electrolysis. Int J Hydrogen Energy 2013;38:3523-36. doi:10.1016/j.ijhydene.2013.01.065.

5. Aricò AS, Siracusano S, Briguglio N, Baglio V, Di Blasi A, Antonucci V. Polymer electrolyte membrane water electrolysis: Status of technologies and potential applications in combination with renewable power sources. J Appl Electrochem 2013;43:107-18. doi:10.1007/s10800-0120490-5. 
6. Acar C, Dincer I. Comparative assessment of hydrogen production methods from renewable and non-renewable sources. Int J Hydrogen Energy 2014;39:1-12. doi:10.1016/j.ijhydene.2013.10.060.

7. Coutanceau C, Baranton S. Electrochemical conversion of alcohols for hydrogen production: a short overview. Wiley Interdiscip Rev Energy Environ 2016;5:388-400. doi:10.1002/wene.193.

8. Miller H, Vizza F, Fornasiero P, Co-production of hydrogen and chemicals by electrochemical reforming of biomass-derived alcohols In: van de Voorde M, Sels B editors. Nanotechnology in Catalysis: Applications in the Chemical Industry, Energy Development and Environment Protection, Wiley-VCH Verlag GmbH\&Co; 2017, doi: 10.1002/9783527699827.ch36

9. Ju HK, Giddey S, Badwal SPS, Mulder RJ. Electro-catalytic conversion of ethanol in solid electrolyte cells for distributed hydrogen generation. Electrochim Acta 2016;212:744-57. doi:10.1016/j.electacta.2016.07.062.

10. Altarawneh BM, Pickup PG. Product distributions and efficiencies for ethanol oxidation in a proton exchange membrane electrolysis cell. J. Electrochem. Soc. 2017; 164: F861-865. doi: $10.1149 / 2.0051709$ jes.

11. Cantane DA, Ambrosio WF, Chatenet M, Lima FHB. Electro-oxidation of ethanol on $\mathrm{Pt} / \mathrm{C}, \mathrm{Rh} / \mathrm{C}$ and $\mathrm{Pt} / \mathrm{Rh} / \mathrm{C}$-based electrocatalysts investigated by on-line DEMS. J. Electroanal. Chem. 2012; 681: 56-65. doi: 10.1016/j.jelechem.2012.05.024.

12. Wang H, Jusys Z, Behm RJ. Ethanol electrooxidation on a carbon-supported Pt catalyst: Reaction kinetics and product yields. J. Phys. Chem. B. 2004; 108(50): 19413-19424. doi: 10.1021/jp046561k

13. Diaz V, Ohanian M, Zinola CF. Kinetics of methanol electrooxidation on $\mathrm{Pt} / \mathrm{C}$ and $\mathrm{PtRu} / \mathrm{C}$ catalysts. Int. J. Hydrogen Energy 2010; 35(19): 10539-10546. doi: 10.1016/j.ijhydene.2010.07.135.

14. Tsiouvaras N, Martinez-Huerta MV, Paschos O, Stimming U, Gierro JLG, Pena MA. PtRuMo/C catalysts for direct methanol fuel cells: Effect of the pretreatment on the structural characteristics and methanol electrooxidation. Int. J. Hydrogen Energy 2010; 35(20): 11478-11488. doi: 10.1016/j.ijhydene.2010.06.053.

15. Perez-Rodriguez S, Corengia M, Garcia G. Zinola CF, Lazaro MJ, Pastor E. Gas diffusion electrodes for methanol electrooxidation studied by a new DEMS configuration: Influence of the diffusion layer. Int. J. Hydrogen Energy 2012; 37(8): 7141-7151. doi: 10.1016/j.ijhydene.2011.11.090.

16. Halme A, Selkäinaho J, Noponen T, Kohonen A. An alternative concept for DMFC - Combined electrolyzer and $\mathrm{H}_{2} \quad$ PEMFC. Int $\mathrm{J}$ Hydrogen Energy 2016;41:2154-64. doi:10.1016/j.ijhydene.2015.12.007.

17. Gutiérrez-Guerra N, Jiménez-Vázquez M, Serrano-Ruiz JC, Valverde JL, de Lucas-Consuegra A. Electrochemical reforming vs. catalytic reforming of ethanol: A process energy analysis for hydrogen production. Chem Eng Process Process Intensif 2015;95:9-16. doi:10.1016/j.cep.2015.05.008. 
18. Majone M, Aulenta F, Dionisi D, D'Addario EN, Sbardellati R, Bolzonella D, et al. High-rate anaerobic treatment of Fischer-Tropsch wastewater in a packed-bed biofilm reactor. Water Res 2010;44:2745-52. doi:10.1016/j.watres.2010.02.008.

19. Sasikumar G, Muthumeenal A, Pethaiah SS, Nachiappan N, Balaji R. Aqueous methanol eletrolysis using proton conducting membrane for hydrogen production. Int J Hydrogen Energy 2008;33:5905-10. doi:10.1016/j.ijhydene.2008.07.013.

20. Take T, Tsurutani K, Umeda M. Hydrogen production by methanol-water solution electrolysis. J Power Sources 2007;164:9-16. doi:10.1016/j.jpowsour.2006.10.011.

21. Pham AT, Baba T, Shudo T. Efficient hydrogen production from aqueous methanol in a PEM electrolyzer with porous metal flow field: Influence of change in grain diameter and material of porous metal flow field. Int J Hydrogen Energy 2013;38:9945-53. doi:10.1016/j.ijhydene.2013.05.171.

22. Sethu SP, Ramalinga Viswanathan M, Mani U, Chan SH. Evaluation of impregnated nanocomposite membranes for aqueous methanol electrochemical reforming. Solid State Ionics 2015;283:16-20. doi:10.1016/j.ssi.2015.11.006.

23. Cloutier CR, Wilkinson DP. Electrolytic production of hydrogen from aqueous acidic methanol solutions. Int J Hydrogen Energy 2010;35:3967-84. doi:10.1016/j.ijhydene.2010.02.005.

24. Lamy C, Guenot B, Cretin M, Pourcelly G. (Invited) A Kinetics Analysis of Methanol Oxidation under Electrolysis/Fuel Cell Working Conditions. ECS Trans 2015;66:1-12. doi:10.1149/06629.0001 ecst.

25. Guenot B, Cretin M, Lamy C. Clean hydrogen generation from the electrocatalytic oxidation of methanol inside a proton exchange membrane electrolysis cell (PEMEC): effect of methanol concentration and working temperature. J Appl Electrochem 2015;45:973-81. doi:10.1007/s10800-015-0867-3.

26. Lamy C, Guenot B, Cretin M, Pourcelly G. Kinetics Analysis of the Electrocatalytic Oxidation of Methanol inside a DMFC working as a PEM Electrolysis Cell (PEMEC) to generate Clean Hydrogen. Electrochim Acta 2015;177:352-8. doi:10.1016/j.electacta.2015.02.069.

27. de la Osa AR, Calcerrada AB, Valverde JL, Baranova EA, de Lucas-Consuegra A. Electrochemical reforming of alcohols on nanostructured platinum-tin catalyst-electrodes. Appl Catal B Environ 2015;179:276-84. doi:10.1016/j.apcatb.2015.05.026.

28. Muthumeenal A, Pethaiah SS, Nagendran A. Investigation of SPES as PEM for hydrogen production through electrochemical reforming of aqueous methanol. Renew Energy 2016;91:7582. doi:10.1016/j.renene.2016.01.042.

29. Uhm S, Jeon H, Kim TJ, Lee J. Clean hydrogen production from methanol-water solutions via power-saved electrolytic reforming process. J Power Sources 2012;198:218-22. doi:10.1016/j.jpowsour.2011.09.083.

30. Hu Z, Wu M, Wei Z, Song S, Shen PK. Pt-WC/C as a cathode electrocatalyst for hydrogen production by methanol electrolysis. J Power Sources 2007;166:458-61. doi:10.1016/j.jpowsour.2007.01.083. 
31. Tuomi S, Santasalo-Aarnio A, Kanninen P, Kallio T. Hydrogen production by methanol-water solution electrolysis with an alkaline membrane cell. J Power Sources 2013;229:32-5. doi:10.1016/j.jpowsour.2012.11.131.

32. Caravaca A, De Lucas-Consuegra A, Calcerrada AB, Lobato J, Valverde JL, Dorado F. From biomass to pure hydrogen: Electrochemical reforming of bio-ethanol in a PEM electrolyser. Appl Catal B Environ 2013;134-135:302-9. doi:10.1016/j.apcatb.2013.01.033.

33. Caravaca A, Sapountzi FM, De Lucas-Consuegra A, Molina-Mora C, Dorado F, Valverde JL. Electrochemical reforming of ethanol-water solutions for pure $\mathrm{H} 2$ production in a PEM electrolysis cell. Int J Hydrogen Energy 2012;37. doi:10.1016/j.ijhydene.2012.03.062.

34. Jablonski A, Lewera A. Electrocatalytic oxidation of ethanol on Pt, Pt-Ru and Pt-Sn nanoparticles in polymer electrolyte membrane fuel cell-Role of oxygen permeation. Appl Catal B Environ 2012;115-116:25-30. doi:10.1016/j.apcatb.2011.12.021.

35. Lamy C, Jaubert T, Baranton S, Coutanceau C. Clean hydrogen generation through the electrocatalytic oxidation of ethanol in a Proton Exchange Membrane Electrolysis Cell (PEMEC): Effect of the nature and structure of the catalytic anode. J Power Sources 2014;245:927-36. doi:10.1016/j.jpowsour.2013.07.028.

36. De Lucas-Consuegra A, De La Osa AR, Calcerrada AB, Linares JJ, Horwat D. A novel sputtered $\mathrm{Pd}$ mesh architecture as an advanced electrocatalyst for highly efficient hydrogen production. J Power Sources 2016;321:248-56. doi:10.1016/j.jpowsour.2016.05.004.

37. Chen YX, Lavacchi A, Miller H, Bevilacqua M, Filippi J, Innocenti M, Marchionni A, Oberhauser W, Wang L, Vizza F. Nanotechnology makes biomass electrolysis more energy efficient than water electrolysis. Nat Commun 2014;5:4036. doi:10.1038/ncomms5036.

38. Pushkareva IV, Pushkareva AS, Grigorieva SA, Lyutikova EK, Akel'kina SV, Osina MA, Slavcheva EP, Fateev VN. Electrochemical Conversion of Aqueous Ethanol Solution in an Electrolyzer with a Solid Polymer Electrolyte. Russ J Appl Chem 2016; 89 :2109-2111. doi: 10.1134/S1070427216120260

39. Lamy C, Devadas A, Simoes M, Coutanceau C. Clean hydrogen generation through the electrocatalytic oxidation of formic acid in a Proton Exchange Membrane Electrolysis Cell (PEMEC). Electrochim Acta 2012;60:112-20. doi:10.1016/j.electacta.2011.11.006.

40. Marshall AT, Haverkamp RG. Production of hydrogen by the electrochemical reforming of glycerol-water solutions in a PEM electrolysis cell. Int J Hydrogen Energy 2008;33:4649-54. doi:10.1016/j.ijhydene.2008.05.029.

41. De Paula J, Nascimento D, Linares JJ. Electrochemical reforming of glycerol in alkaline PBIbased PEM reactor for hydrogen production. Chem Eng Trans 2014;41:205-10. doi:10.3303/CET1441035.

42. de Paula J, Nascimento D, Linares JJ. Influence of the anolyte feed conditions on the performance of an alkaline glycerol electroreforming reactor. J Appl Electrochem 2015;45:689-700. doi:10.1007/s10800-015-0848-6.

43. Jonzalez-Cobos J. Baranton S. Coutanceau C. Development of Bismuth-modified PtPd 
nanocatalysts for the electrochemical reforming of polyols into hydrogen and value-added chemicals. ChemElectroChem 2016;3:1694-704.

44. Sapountzi FM, Tsampas MN, Fredrikssson HOA, Gracia JM, Niemantsverdriet JW, Hydrogen from electrochemical reforming of $\mathrm{C} 1-\mathrm{C} 3$ alcohols using proton conducting membranes. Int $\mathrm{J}$ Hydrogen Energy, 2017; 42: 10762-10774, doi: 10.1016/j.ijhydene.2017.02.195

45. De Lucas-Consuegra A, Calcerrada AB, De La Osa AR, Valverde JL. Electrochemical reforming of ethylene glycol. Influence of the operation parameters, simulation and its optimization. Fuel Process Technol 2014;127:13-9. doi:10.1016/j.fuproc.2014.06.010.

46. Miller, H.A.; Bellini, M.; Vizza, F.; Hasenohrl, C.; Tilley RD. Carbon supported Au-Pd coreshell nanoparticles for hydrogen production by alcohol electroreforming. Catal Sci Technol 2016;6:6870-8.

47. Liu W, Cui Y, Du X, Zhang Z, Chao Z, Deng Y. High efficiency hydrogen evolution from native biomass electrolysis, :Energy Environ Sci 2016; 9, 467-472, doi: 10.1039/c5ee03019f

48. Pagliaro MV, Bellini M, Bevilacqua M, Filippi J, Folliero MG, Marchionni A, Miller HA, Oberhauser W, Caporali S, Innocenti M, Vizza F, RSC Adv 2017;7: 13971-13978, doi: 10.1039/C7RA00044H

49. Guenot B, Cretin M, Lamy C, Electrochemical reforming of diomethoxymethane in a Proton Exchange Membrane Electrolysis Cell: A way to generate clean hydrogen for low temperature fuel cells. Int J Hydrogen Energy 2017: 42: 28128-28139, doi: 10.1016/j.jhydene.2017.09.028

50. Liu L, Atomic Layer Deposition of Electrocatalysts for Use in Fuel Cells and Electrolyzers In: Bachmann J, editor. Atomic Layer Deposition in Energy Conversion Applications 2017, WileyVCH Verlag GmbH\&Co KGaA, Weinheim, Germany,2017, doi: 10.1002/9783527694822.ch5

51. Mackus AJM, Weber MJ, Thissen NFW, Garcia-Alonso D, Vervuurt RHJ, Assali S, Bol AA, Verheijen MA, Kessels WMM. Atomic layer deposition of Pd and Pt nanoparticles for catalysis: on the mechanisms of nanoparticle formation, Nanotechnology 2016;27:034001. doi: $10.1088 / 0957-4484 / 27 / 3 / 034001$

52. Hajara Y, Di Palma V, Kyriakou V, Verheijen MA, Baranova EA, Vernoux P, Kessels WMM, Creatore M, van de Sanden MCM, Tsampas MN. Atomic layer deposition of highly dispersed Pt nanoparticles on a high surface area electrode backbone for electrochemical promotion of catalysis. Electrochem Commun 2017;84:40-44. doi: 10.1016/j.elecom.2017.09.023

53. Penchev H, Borisov G, Petkucheva E, Ublekov F, Sinigersky V, Radev I, Slavcheva E; Highly $\mathrm{KOH}$ doped para-polybenzimidazole anion exchange membrane and its performance in $\mathrm{Pt} / \mathrm{Ti}_{\mathrm{n}} \mathrm{O}_{2 \mathrm{n}}$ 1 catalyzed water electrolysis cell. Materials Letters 2018; 221: 128-130, doi: 10.1016/j.matlet.2018.03.094

54. Stoll T, Zafeiropoulos G, Tsampas MN. Solar fuel production in a novel polymeric electrolyte membrane photoelectrochemical (PEM-PEC) cell with a web of titania nanotube arrays as photoanode and gaseous reactants. Int J Hydrogen Energy 2016;41:17807-17, doi:10.1016/j.ijhydene.2016.07.230

55. Knoops HCM, Mackus AJM, Donder ME, van de Sanden MCM, Notten PHL, Kessels WMM. 
ALD of platinum and platinum oxide films. Electrochem Solid-State Lett 2009;12: G34-G36.

56. Niemantsverdriet JW, Spectroscopy in Catalysis, $3^{\text {rd }}$ Edition, Wiley-VCH, Weinheim; 2007. doi: $10.1002 / 9783527611348$

57. Barradas NP, Jeynes C. Advanced physics and algorithms in the IBA DataFurnace. Nucl Instrum Phys Res B 2008; 266: 1875-1879, doi: 10.1016/j.nimb.2007.10.044

58. Hsueh YC, Wang CC, Kei CC, Lin YH, Liu C, Perng TP. Fabrication of catalyst by atomic layer deposition for high specific power density proton exchange membrane fuel cells. J Catal 2012;294:63-68. doi:10.1016/j.jcat.2012.07.006

59. Zeng K, Zhang D. Recent progress in alkaline water electrolysis for hydrogen production and applications. Prog Energy Combust Sci 2010; 36: 307-326. doi: 10.1016/j.pecs.2009.11.002

60. Modibedi RM, Ozoemen KI, Mathe MK. Palladium-based nanocatalysts for alcohol electrooxidation in alkaline media. In: Shao M, editor. Electrocatal. fuel cells A non- low- Platin. approach, London: Springer-Verlag; 2013, p. 129-56.

61. Tripkovic AV, Popovic KD, Grgur BN, Blizanac B, Ross PN, Markovic NM, Methanol electrooxidation on supported $\mathrm{Pt}$ and $\mathrm{PtRu}$ catalysts in acid and alkaline solutions. Electrochim Acta 2002; 47(22): 3707-3714

62. Lai SCS, Kleijn SEF, Ozturk FTZ, van Rees Vellinga VC, Koning J, Rodriguez P, Koper MTM, Effects of electrolyte $\mathrm{pH}$ and composition on the ethanol electro-oxidation reaction. Catal Today 2010; 154: 92-104, doi: 10.1016/j.cattod.2010.01.060

63. Zeng L, Zhao TS, An L, Zhao G, Yan XH, Physicochemical properties of alkaline doped polybenzimidazole membranes for anion exchange membrane fuel cells. J Membr Sci 2015; 439: 340-348, doi: 10.1016/j.memsci.2015.06.013

64. Zarrin H, Jiang G, Lam GYY, Fowler M, Chen Z, High performance porous polybenzimidazolemembrane for alkaline fuel cells. Int J Hydrogen Energy 2014; 39:1840518415, doi: 10.1016/j.ijhydene.2014.08.134

65. Jensen JO, Aili D, Hansen MK, Li Q, Bjerrum NJ, Christensen E, A stability study of alkali doped PBI membranes for alkaline electrolyzer cells. ECS Transactions 2014: 64 (3):1175-1184, doi: $10.1149 / 06403.1175$ ecst

66. Gilliam RJ, Graydon JW, Kirk DW, Thorpe SJ, A review of specific conductivities of potassium hydroxide solutions for various concentrations and temperatures. Int J Hydrogen Energy 2007; 32:359 - 364, doi: 10.1016/j.ijhydene.2006.10.062

67. Ublekov F, Radev I, Sinigersky V, Natova M, Penchev H. Composite anion conductive membranes based on para-polybenzimidazole and Montmorillonite. Mater Lett 2018; 219:131133. doi: $10.1016 /$ j.matlet.2018.02.082

68. Calcerrada AB, de la Osa A, Llanos J, Dorado F, de Lucas-Consuegra A. Hydrogen from electrochemical reforming of ethanol assisted by sulfuric acid addition. Appl Catal B 2018; 231:310-316. doi: 10.1016/j.apcatb.2018.03.028

69. Cheng N, Shao Y, Liu J, Sun X. Electrocatalysts by atomic layer deposition for fuel cell applications. Nano Energy 2016; 29:220-242 doi: 10.1016/j.nanoen.2016.01.016 
70. Hasa B, Vakros J, Katsaounis AD. Effect of $\mathrm{TiO} 2$ on Pt-Ru-based anodes for methanol electroreforming. Appl. Catal. B. 2018; 237:811-816. doi:10.1016/j.apcatb.2018.06.055

71. Lim C, Scott K, Allen RG, Roy S. Direct Methanol Fuel Cells Using Thermally Catalysed Ti Mesh. J Appl Electrochem 2004; 34:929-933, doi: 10.1023/B:JACH.0000040497.03256.36

72. Shao ZG, Lin WF, Christensen PA, Zhang H. Ti mesh anodes prepared by electrochemical deposition for the direct methanol fuel cell. Int J Hydrogen energy 2006; 31:1914-1919, doi:10.1016/j.ijhydene.2006.05.003

73. De Souza RFB, Buzzo GS, Silva JCM, Spinace EV, Neto AO, Assumpcao MHMT. Effect of $\mathrm{TiO}_{2}$ Content on Ethanol Electrooxidation in Alkaline Media Using Pt Nanoparticles Supported on Physical Mixtures of Carbon and $\mathrm{TiO}_{2}$ as Electrocatalysts Electrocatalysis 2014; 5:213219.doi:10.1007/s12678-014-0183-4

74. Yoo SJ, Jeon TY, Lee KS, Park KW, Sung YE. Effects of particle size on surface electronic and electrocatalytic properties of $\mathrm{Pt} / \mathrm{TiO}_{2}$ nanocatalysts. Chem Commun 2010; 46:794-796, doi:

600

601

602

603

604

605

606

607 10.1039/B916335B

75. Park SB, Park YI, Fabrication of Gas Diffusion Layer (GDL) Containing Microporous Layer Using Flourinated Ethylene Prophylene (FEP) for Proton Exchange Membrane Fuel Cell (PEMFC). Int J Precis Eng Manuf 2012; 13: 1145-1151, doi: 10.1007/s12541-012-0152-X

76. Su H, Sita C, Pasupathi S. The effect of gas diffusion layer PTFE content on the performance of high temperature proton exchange membrane fuel cell. Int J Electrochem Sci 2016; 11: 2919 2926. doi: 10.20964/110402919

608 


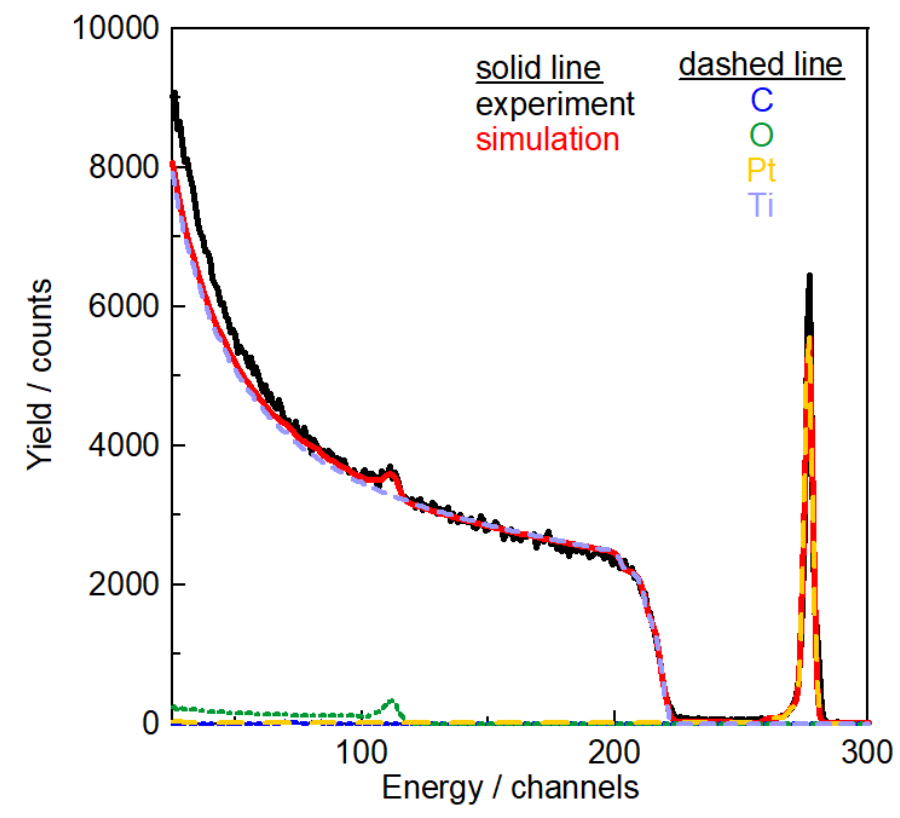

Figure S1. The experimental (solid black line) and simulated (solid red line) RBS spectrum of the $\mathrm{Pt} / \mathrm{TiO}_{2}$ Ti sample. The simulated elemental contributions are over-plotted using dashed lines. The legend indicates the corresponding elements.

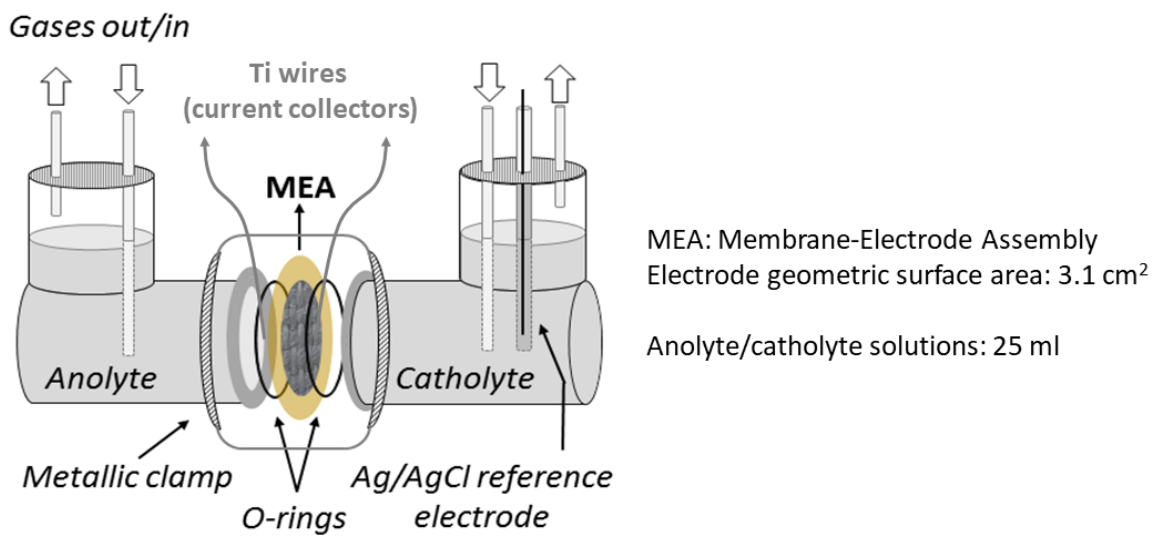

Figure S2. Schematic representation of the electrochemical cell. The two chambers are separated by the MEA and a metallic clamp is used to hold together the assembly. The $\mathrm{Ag} / \mathrm{AgCl}$ reference is inserted at the cathodic chamber. 